Review Article

\title{
Recent Developed Strategies for Enhancing Chondrogenic Differentiation of MSC: Impact on MSC-Based Therapy for Cartilage Regeneration
}

\author{
Kangkang Zha, ${ }^{1,2,3}$ Zhiqiang Sun, ${ }^{1,2,3}$ Yu Yang, ${ }^{4}$ Mingxue Chen, ${ }^{5}$ Cangjiang Gao, ${ }^{1,2,3}$ \\ Liwei Fu, ${ }^{1,2,3}$ Hao Li, ${ }^{1,2,3}$ Xiang Sui, ${ }^{2}$ Quanyi Guo $\left(\mathbb{1},{ }^{2}\right.$ and Shuyun Liu $\left(\mathbb{C}^{2}\right.$ \\ ${ }^{1}$ Medical School of Chinese PLA, Beijing, China \\ ${ }^{2}$ Institute of Orthopaedics, Chinese PLA General Hospital; Beijing Key Lab of Regenerative Medicine in Orthopaedics, Key Laboratory \\ of Musculoskeletal Trauma \& War Injuries, PLA, 28 Fuxing Road, Haidian District, Beijing, China \\ ${ }^{3}$ School of Medicine, Nankai University, Tianjin, China \\ ${ }^{4}$ The Second People's Hospital of Guiyang, Guiyang, Guizhou, China \\ ${ }^{5}$ Department of Orthopaedic Surgery, Beijing Jishuitan Hospital, Fourth Clinical College of Peking University, Beijing, China
}

Correspondence should be addressed to Quanyi Guo; doctorguo_301@163.com and Shuyun Liu; clear_ann@163.com

Received 25 September 2020; Revised 20 February 2021; Accepted 4 March 2021; Published 22 March 2021

Academic Editor: Yangzi Jiang

Copyright () 2021 Kangkang Zha et al. This is an open access article distributed under the Creative Commons Attribution License, which permits unrestricted use, distribution, and reproduction in any medium, provided the original work is properly cited.

\begin{abstract}
Articular cartilage is susceptible to damage, but its self-repair is hindered by its avascular nature. Traditional treatment methods are not able to achieve satisfactory repair effects, and the development of tissue engineering techniques has shed new light on cartilage regeneration. Mesenchymal stem cells (MSCs) are one of the most commonly used seed cells in cartilage tissue engineering. However, MSCs tend to lose their multipotency, and the composition and structure of cartilage-like tissues formed by MSCs are far from those of native cartilage. Thus, there is an urgent need to develop strategies that promote MSC chondrogenic differentiation to give rise to durable and phenotypically correct regenerated cartilage. This review provides an overview of recent advances in enhancement strategies for MSC chondrogenic differentiation, including optimization of bioactive factors, culture conditions, cell type selection, coculture, gene editing, scaffolds, and physical stimulation. This review will aid the further understanding of the MSC chondrogenic differentiation process and enable improvement of MSC-based cartilage tissue engineering.
\end{abstract}

\section{Introduction}

Articular cartilage damage is commonly seen in clinical practice and is often caused by trauma, progressive osteoarthritis (OA), and rheumatoid arthritis (RA). Due to its avascular nature, it is difficult for articular cartilage to undergo selfhealing [1]. At present, common methods used for articular cartilage regeneration are microfracture [2], particulated articular cartilage implantation [3], osteochondral allograft or autograft transplantation $[4,5]$, and autologous chondrocyte implantation [6]. However, these techniques are limited in their ability to form hyaline cartilage. The development of cartilage tissue engineering strategies over the past few decades has provided a new approach for cartilage regenera- tion, which consists of three elements: seed cells, scaffolds, and growth factors [7].

Among various cell types, mesenchymal stem cells (MSCs) are one of the most promising seed cells for cartilage tissue engineering. MSCs are pluripotent adult stem cells that exhibit self-renewal, multipotent differentiation, and immunomodulation functions [8]. The International Society for Cellular Therapy has proposed the following standard criteria for MSCs: (1) MSCs must be plastic adherent in standard culture conditions; (2) MSCs must express CD105, $\mathrm{CD} 73$, and CD90 and not express CD45, CD34, CD14 or CD11b, CD79 $\alpha$ or CD19, and HLA-DR; and (3) MSCs must be able to differentiate into osteoblasts, chondroblasts, and adipocytes in vitro [9]. A large number of basic studies and 
clinical trials employing MSCs for articular cartilage regeneration have been reported. Intra-articular injection of MSCs has been proven to be safe and effective for improving patients' pain, symptoms, and quality of life [10].

However, MSCs tend to lose their cellular functions, including their self-renewal ability and multipotency, after isolation and in vitro expansion, which could in part explain the treatment failures of several MSC-based clinical trials [11]. Numerous studies have indicated that under specific conditions, MSCs can form cartilage-like tissues that contain a certain amount of typical cartilaginous biomolecules, such as type II collagen (COL II), proteoglycans, and aggrecan. However, the composition and structure of the resulting differentiated tissues rarely reach the level of native cartilage. It has been proposed that the collagen content in tissueengineered cartilage is generally less than $50 \%$ of that in native cartilage. In addition, the stratified ultrastructure and spatial organization of native cartilage is often not seen in tissue-engineered cartilage, which results in unsatisfactory mechanical properties [12]. Therefore, differentiating MSCs into normal chondrocytes and maintaining their physiological function are goals that need to be achieved in the field of cartilage regeneration. The regulation of MSC chondrogenic differentiation represents an area that has attracted an enormous amount of research, which is favorable for further understanding of the chondrogenic differentiation process and the optimization of MSC-based cartilage regenerative strategies [13].

In this review, we described the chondrogenic differentiation process of MSCs and then summarized the recent advances in enhancement strategies for MSC chondrogenic differentiation, including optimization of bioactive factors (Table 1), culture conditions, cell type selection, coculture, gene editing, scaffolds, and physical stimulation (Table 2). This review will help to improve the therapeutic effect of MSC-based therapy for cartilage regeneration.

\section{Chondrogenic Differentiation Process of MSCs}

The cartilage is a connective tissue that is composed of chondrocytes and their surrounding matrix, which mainly contains collagens and proteoglycans. Chondrogenesis, the formation of chondrocytes and cartilage tissues, leads to the development of the various types of cartilage, including hyaline, fibrous, and elastic cartilages [14]. MSCs possess multipotent differentiation potential and can differentiate into numerous mesodermal cell types, such as chondrocytes, osteoblasts, adipocytes, and myofibroblasts [15]. In the process of chondrogenic differentiation, MSCs are thought to follow an endochondral ossification procedure, which includes five main stages (Figure 1). First, in the presence of certain paracrine factors, MSCs produce extracellular matrix (ECM) containing hyaluronan, collagen type I (COL I), and COL II and then undergo increased condensation through cell-ECM and cell-cell interactions. Second, MSCs differentiate into chondrocytes under the influence of a branch of transcription factors, such as Smads, p38, RhoA/ROCK, and SOX9. Third, differentiated chondrocytes proliferate rapidly and secrete
ECM. Fourth, mature chondrocytes take on a hypertrophic phenotype and begin to express collagen type X (COL X) and alkaline phosphatase. Fifth, hypertrophic chondrocytes are replaced with blood vessels after cell death [14].

The differentiation of MSCs into chondrocytes requires a dynamic balance of various promoters and inhibitors. The microenvironment consists of soluble cytokines, surrounding matrix, nearby cells, and physical stimuli, all of which play an important role in determining the cellular fates and chondrogenic differentiation of MSCs (Figure 2). However, after differentiating into mature chondrocytes, MSCs may undergo cellular hypertrophy followed by vascular penetration, marrow deposition, and ossification. Exploring potential methods to inhibit unexpected chondrocyte hypertrophy and osteogenic differentiation could help to maintain the phenotype of mature chondrocytes differentiated from MSCs.

\section{Bioactive Factors}

3.1. Cytokines. Among the multiple cytokines required for initiating MSC chondrogenic differentiation, transforming growth factor beta (TGF- $\beta$ ) is the most commonly used [16]. TGF- $\beta$ exists in three isoforms, TGF- $\beta 1$, TGF- $\beta 2$, and TGF- $\beta 3$, and has two receptors, TGF- $\beta$ receptors I (TGF- $\beta$ $\mathrm{RI})$ and II (TGF- $\beta$ RII). After binding with TGF- $\beta$ RI or TGF- $\beta$ RII, TGF- $\beta$ induces MSC chondrogenic differentiation mainly through the activation of the TGF- $\beta /$ Smad signaling pathway. Phosphorylated Smad2/3 binds to Smad4 and translocates into the nucleus, resulting in the expression of SOX9 and COL II [17]. Xu et al. indicated that the activation of RhoA/ROCK was also involved in TGF- $\beta$-induced chondrogenic differentiation of rat synovium-derived MSCs (SDSCs) through interaction with the Smad pathway [18]. MAPK signaling is another pathway through which TGF- $\beta$ regulates MSC chondrogenic differentiation, and in this pathway, p38 promotes chondrogenic differentiation of human bone marrow-derived mesenchymal stem cells (BMSCs), while ERK-1 suppresses BMSC chondrogenic differentiation [19]. Bone morphogenetic proteins (BMPs) are members of the TGF- $\beta$ superfamily and also participate in regulating human BMSC (hBMSC) chondrogenic differentiation. Among BMPs, BMP2, BMP4, BMP6, and BMP7 are the most widely employed for BMSC chondrogenic differentiation $[20,21]$.

In addition to TGF- $\beta$ and BMPs, other cytokines have also been shown to enhance MSC chondrogenic differentiation. For example, Hagmann et al. revealed that the addition of fibroblast growth factor-2 (FGF-2) during the in vitro expansion of hBMSCs significantly enhanced their chondrogenic differentiation with no influence on their adipogenic or osteogenic differentiation [22]. Jeong et al. found that thrombospondin- 2 not only promoted the chondrogenic differentiation of the human umbilical cord blood-derived mesenchymal stem cells (UCBSCs) through the activation of the Notch signaling pathway but also attenuated their hypertrophic differentiation [23].

3.2. KGN. Although cytokines play vital roles in inducing MSC chondrogenic differentiation, their applications may 
TABLE 1: Effects of different bioactive factors on MSC chondrogenic differentiation.

\begin{tabular}{|c|c|c|c|c|c|}
\hline $\begin{array}{l}\text { Bioactive } \\
\text { factors }\end{array}$ & Cell type & Signaling pathway & Dose & Effect & Ref. \\
\hline TGF- $\beta 3$ & $\begin{array}{l}\text { Human } \\
\text { BMSCs }\end{array}$ & $\begin{array}{l}\text { Activate TGF- } \beta / \text { Smad } \\
\text { pathway }\end{array}$ & $10 \mathrm{ng} / \mathrm{mL}$ & Promote MSC chondrogenic differentiation & $\begin{array}{l}{[16,} \\
17]\end{array}$ \\
\hline \multirow{2}{*}{ TGF- $\beta 1$} & Rat SDSCs & $\begin{array}{l}\text { Activate RhoA/ROCK } \\
\text { pathway and Smad pathway }\end{array}$ & $10 \mathrm{ng} / \mathrm{mL}$ & $\begin{array}{l}\text { Induce gene expression of } S O X 9, C O L I, C O L I I \text {, and } \\
\qquad A C A N\end{array}$ & [18] \\
\hline & $\begin{array}{l}\text { Human } \\
\text { BMSCs }\end{array}$ & $\begin{array}{l}\text { Activate MAPK pathway and } \\
\text { Wnt pathway }\end{array}$ & $10 \mathrm{ng} / \mathrm{mL}$ & $\begin{array}{l}\text { Induce gene expression of } S O X 9, C O L I I \text {, and } A C A N \text { and } \\
\text { proteoglycan synthesis }\end{array}$ & {$[19]$} \\
\hline BMPs & $\begin{array}{l}\text { Human } \\
\text { ADSCs and } \\
\text { BMSCs }\end{array}$ & NA & $500 \mathrm{ng} / \mathrm{mL}$ & $\begin{array}{l}\text { BMP-2, BMP-4, BMP- } 6 \text {, and BMP-7 are effective } \\
\text { enhancers of MSC chondrogenic differentiation }\end{array}$ & [21] \\
\hline FGF-2 & $\begin{array}{l}\text { Human } \\
\text { BMSCs }\end{array}$ & NA & $10 \mathrm{ng} / \mathrm{mL}$ & Increase GAG/DNA content & [22] \\
\hline TSP-2 & $\begin{array}{l}\text { Human } \\
\text { UCBSCs }\end{array}$ & Activate Notch pathway & NA & $\begin{array}{l}\text { Promote the chondrogenic differentiation of MSCs and } \\
\text { attenuate their hypertrophic differentiation }\end{array}$ & [23] \\
\hline \multirow{4}{*}{ KGN } & $\begin{array}{l}\text { Human } \\
\text { ADSCs }\end{array}$ & NA & $100 \mathrm{nM} / \mathrm{L}$ & $\begin{array}{l}\text { Promote chondrogenic differentiation and suppress } \\
\text { chondrocyte hypertrophy in MSCs }\end{array}$ & [30] \\
\hline & $\begin{array}{l}\text { Human } \\
\text { SDSCs }\end{array}$ & $\begin{array}{l}\text { Activate BMP-7/Smad5 } \\
\text { pathway }\end{array}$ & $\begin{array}{l}1 \mu \mathrm{M} / \mathrm{L} \\
\text { and } \\
10 \mu \mathrm{M} / \mathrm{L}\end{array}$ & Increase gene expression of $C O L I I$ and $A C A N$ & [32] \\
\hline & $\begin{array}{l}\text { Human } \\
\text { UCMSCs }\end{array}$ & $\begin{array}{l}\text { Activate JNK/RUNX1 } \\
\text { pathway and suppress } \beta \text { - } \\
\text { catenin/RUNX2 pathway }\end{array}$ & $1 \mu \mathrm{M} / \mathrm{L}$ & $\begin{array}{c}\text { Elevate accumulation of extracellular matrix and } \\
\text { chondrogenic gene expression of SOX9, COL II, and } \\
\text { ACAN }\end{array}$ & [33] \\
\hline & $\begin{array}{l}\text { Human } \\
\text { BMSCs }\end{array}$ & NA & $100 \mathrm{nM} / \mathrm{L}$ & $\begin{array}{c}\text { Increase gene expression of SOX9, RUNX2, SERPINB2, } \\
\text { and SERPINA9 }\end{array}$ & [34] \\
\hline \multirow{2}{*}{ Melatonin } & $\begin{array}{l}\text { Human } \\
\text { BMSCs }\end{array}$ & $\begin{array}{l}\text { Attenuate IL- } 1 \beta \text {-induced } \\
\text { activation of NF- } \kappa \text { B pathway }\end{array}$ & $50 \mathrm{nM} / \mathrm{L}$ & Save IL- $1 \beta$-impaired MSC chondrogenic differentiation & [41] \\
\hline & $\begin{array}{l}\text { Human } \\
\text { BMSCs }\end{array}$ & NA & $50 \mathrm{nM} / \mathrm{L}$ & Enhance accumulation of GAG, COL II, and COL X & [42] \\
\hline CS & $\begin{array}{c}\text { Goat } \\
\text { BMSCs }\end{array}$ & NA & $\begin{array}{r}\text { CS-based } \\
\text { hydrogels }\end{array}$ & $\begin{array}{l}\text { Promote MSC chondrogenic differentiation and inhibit } \\
\text { chondrocyte hypertrophy }\end{array}$ & [45] \\
\hline Ghrelin & Rat BMSCs & $\begin{array}{l}\text { Enhance phosphorylation of } \\
\text { ERK1/2 and DMNT3A }\end{array}$ & $10 \mathrm{nM} / \mathrm{L}$ & $\begin{array}{l}\text { Upregulate expression of COL II, SOX9, and ACAN and } \\
\text { enhance accumulation of collagen and GAG in vitro; } \\
\text { improve cartilage repair effect of BMSCs in vivo }\end{array}$ & [50] \\
\hline Atractylenolides & Rat BMSCs & Activate $\mathrm{SHH}$ pathway & $30 \mu \mathrm{g} / \mathrm{mL}$ & Increase gene expression of $S O X 9, C O L I I$, and $A C A N$ & [51] \\
\hline FSTL-1 & $\begin{array}{l}\text { Mouse } \\
\text { MSCs }\end{array}$ & Activate TGF- $\beta$ pathway & $5 \mu \mathrm{g} / \mathrm{mL}$ & Upregulate expression of $S O X 9$ and $C O L I I$ & [53] \\
\hline
\end{tabular}

TGF- $\beta$ : transforming growth factor beta; BMSCs: bone marrow-derived mesenchymal stem cells; MSCs: mesenchymal stem cells; SDSCs: synovial membranederived mesenchymal stem cells; BMPs: bone morphogenetic proteins; ADSCs: adipose tissue-derived mesenchymal stem cells; NA: not applicable; FGF-2: fibroblast growth factor-2; GAG: glycosaminoglycan; TSP-2: thrombospondin-2; UCBSCs: umbilical cord blood-derived mesenchymal stem cells: KGN: kartogenin; UCMSCs: umbilical cord-derived mesenchymal stem cells; COL II: type II collagen; COL X: type X collagen; CS: chondroitin sulfate; FSTL-1: follistatin-like protein-1.

be restricted due to their short half-life and high cost. Recently, some small molecules have been found to enhance MSC chondrogenic differentiation, and these molecules are particularly intriguing because of their stability and low cost [24]. Kartogenin (KGN), first discovered by Johnson in 2012 [25], is an important small molecule that facilitates MSC chondrogenic differentiation and has drawn considerable interest in recent years [26-28]. Compared with TGF- $\beta$, KGN seems to induce a weaker promotion of chondrogenic differentiation but a greater suppression of chondrocyte hypertrophy in human adipose tissue-derived MSCs (ADSCs) [29, 30]. In addition, the combination of KGN and TGF- $\beta 3$ has synergistic effects, as human umbilical cord-derived mesenchymal stem cells (UCMSCs) treated with KGN and TGF- $\beta 3$ were shown to secrete more COL II than MSCs treated with TGF- $\beta 3$ or KGN alone [31]. Zhou et al. reported that $\mathrm{KGN}$ can induce the differentiation of human SDSCs (hSDSCs) into chondrocytes through the activation of the BMP-7/Smad5 signaling pathway [32]. In addition, Jing et al. revealed that human UCMSCs (hUCMSCs) preconditioned with KGN were stalled in a precartilaginous stage with the activation of JNK/RUNX1 pathway and suppression of $\beta$-catenin/RUNX2 pathway [33]. After induction of chondrogenic differentiation by KGN, hBMSCs expressed significantly increased expression levels of SERPINA9 and SERPINB2, which may serve as novel differentiation markers for MSC lineage commitment toward cartilage [34]. Several biomaterials have been synthesized to improve MSC 
TABLE 2: Effects of different physical stimulation on MSC chondrogenic differentiation.

\begin{tabular}{|c|c|c|c|c|c|}
\hline Physical stimuli & Cell type & Mechanism & Manner & Effect & Ref. \\
\hline Vibration & Rat BMSCs & $\begin{array}{l}\text { Activate } \mathrm{Wnt} / \beta \text {-catenin } \\
\text { pathway }\end{array}$ & $\begin{array}{l}\text { Low-magnitude }(0.49 \mathrm{~g}) \text { and high- } \\
\text { frequency }(40 \mathrm{~Hz}) \text { vibration } \\
(30 \mathrm{~min} / \text { day, } 21 \text { days })\end{array}$ & $\begin{array}{l}\text { Promote MSC chondrogenic } \\
\text { differentiation and inhibit } \\
\text { hypertrophic differentiation }\end{array}$ & [123] \\
\hline Tensile & $\begin{array}{l}\text { Rabbit } \\
\text { BMSCs }\end{array}$ & NA & $\begin{array}{l}\text { Cyclic dynamic square wave tensile } \\
\text { at } 5,10,15 \text {, and } 20 \% \text { of strain, } 0.5 \mathrm{~Hz} \\
(4 \mathrm{~h} / \text { day, } 10 \text { days })\end{array}$ & $\begin{array}{l}\text { Improve chondrogenic } \\
\text { phenotype of MSCs }\end{array}$ & [124] \\
\hline \multirow{2}{*}{ Compression } & $\begin{array}{l}\text { Human } \\
\text { BMSCs }\end{array}$ & $\begin{array}{c}\text { Activate TGF- } \\
\beta / \text { Activin/nodal pathway } \\
\text { and suppress BMP/GDP and } \\
\text { integrin/FAK/ } \\
\text { ERK pathways }\end{array}$ & $\begin{array}{l}\text { Cyclic dynamic compression force at } \\
5 \% \text { of strain, } 1 \mathrm{~Hz}(2 \mathrm{~h} / \text { day, } 21 \text { days })\end{array}$ & $\begin{array}{l}\text { Enhance MSC chondrogenic } \\
\text { differentiation and suppress } \\
\text { chondrocyte hypertrophy }\end{array}$ & [125] \\
\hline & $\begin{array}{l}\text { Rabbit } \\
\text { BMSCs }\end{array}$ & EKK patnways & $\begin{array}{l}\text { Cyclic dynamic compression force at } \\
10 \% \text { of Strain, } 1 \mathrm{~Hz}(2 \mathrm{~h} \text { /day, } 21 \text { days })\end{array}$ & $\begin{array}{l}\text { Enhance MSC chondrogenic } \\
\text { differentiation and suppress } \\
\text { chondrocyte hypertrophy and } \\
\text { fibrocartilage formation }\end{array}$ & {$[126]$} \\
\hline \multirow[t]{2}{*}{ Microgravity } & $\begin{array}{l}\text { Rabbit } \\
\text { BMSCs }\end{array}$ & $\begin{array}{l}\text { Suppress IHH and } \mathrm{SHH} \\
\text { pathways }\end{array}$ & Rotation at $12-14 \mathrm{rpm}$ for 21 days & $\begin{array}{c}\text { Enhance chondrogenic } \\
\text { differentiation and attenuate } \\
\text { chondrocyte hypertrophy and } \\
\text { aging of MSCs }\end{array}$ & {$[28]$} \\
\hline & $\begin{array}{l}\mathrm{C} 3 \mathrm{H} 10 \mathrm{~T} 1 / 2 \\
\text { cells }\end{array}$ & NA & $\begin{array}{l}\text { LIPUS at } 30 \mathrm{~mW} / \mathrm{cm}^{2}, 1 \mathrm{MHz} \text { with a } \\
\text { pulse duration of } 200 \mu \text { s repeated at } \\
\qquad 100 \mathrm{~Hz}(20 \mathrm{~min} / \text { day })\end{array}$ & $\begin{array}{l}\text { Increase the expression of } \\
\text { COL II and SOX9 }\end{array}$ & [127] \\
\hline \multirow[t]{2}{*}{ LIPUS } & Rat BMSCs & Inhibit cell autophagy & $\begin{array}{l}\text { LIPUS at } 50 \mathrm{~mW} / \mathrm{cm}^{2} \text {, on-off ratio of } \\
20 \% \text {, and irradiated with } 3 \mathrm{MHz} \text { for } \\
20 \mathrm{~min} \text { (once a day, } 10 \text { days) }\end{array}$ & $\begin{array}{l}\text { Increase cartilage-like ECM } \\
\text { accumulation and gene } \\
\text { expression of COL II, SOX9, } \\
\text { and ACAN }\end{array}$ & [128] \\
\hline & $\begin{array}{l}\text { Rabbit } \\
\text { BMSCs }\end{array}$ & NA & $\begin{array}{c}\text { MSC-seeded PGA scaffold was } \\
\text { subcutaneously implanted into } \\
\text { mouse and treated with LIPUS at } \\
200 \mathrm{~mW} / \mathrm{cm}^{2}, 0.8 \mathrm{~Hz}(10 \mathrm{~min} / \mathrm{day}, 4 \\
\text { weeks) }\end{array}$ & $\begin{array}{l}\text { Increase collagen and GAG } \\
\text { content and mechanical } \\
\text { properties of the scaffold }\end{array}$ & [129] \\
\hline \multirow{3}{*}{ Electric field } & $\begin{array}{l}\text { Human } \\
\text { ADSCs }\end{array}$ & NA & $\begin{array}{l}\text { Electric field at } 20 \mathrm{mv} / \mathrm{cm}, 1 \mathrm{kHz} \\
\quad(20 \mathrm{~min} / \text { day, } 7 \text { days })\end{array}$ & $\begin{array}{l}\text { Increase gene expression of } \\
C O L I I \text { and } S O X 9 \text {; decrease } \\
\text { gene expression of COL } I \text { and } \\
C O L X\end{array}$ & [131] \\
\hline & $\begin{array}{l}\text { Mouse } \\
\text { BMSCs }\end{array}$ & $\begin{array}{l}\text { Activate } \mathrm{P}_{2} \mathrm{X}_{4} \text {, TGF- } \beta \text {, and } \\
\text { BMP pathways }\end{array}$ & $\begin{array}{l}\text { Electrical field at } 5 \mathrm{~V} / \mathrm{cm}, 5.0 \mathrm{~Hz} \text { with } \\
\text { a duration of } 8 \mathrm{~ms} \text { for } 3 \text { days }\end{array}$ & $\begin{array}{c}\text { Increase gene expression of } \\
\text { COL II, SOX9 and ACAN and } \\
\text { accumulation of COL II and } \\
\text { GAG }\end{array}$ & [133] \\
\hline & $\begin{array}{l}\text { Swine } \\
\text { BMSCs }\end{array}$ & $\begin{array}{l}\text { Downregulate the } \\
\text { expression of DMMT1 and } \\
\text { increase methylation of the } \\
\text { promoters of OCT4 and } \\
\text { NANOG }\end{array}$ & $\begin{array}{c}\text { Nanosecond pulsed electrical field of } \\
10 \mathrm{~ns} \text { at } 20 \mathrm{kV} / \mathrm{cm} \text { or } 100 \mathrm{~ns} \text { at } \\
10 \mathrm{kV} / \mathrm{cm}, 1 \mathrm{~Hz} \text { for } 14 \text { days }\end{array}$ & $\begin{array}{l}\text { Enhance cartilaginous ECM } \\
\text { accumulation and gene } \\
\text { expression of COL II and } \\
\text { SOX9 }\end{array}$ & [135] \\
\hline \multirow{2}{*}{$\begin{array}{l}\text { Electromagnetic } \\
\text { field }\end{array}$} & $\begin{array}{l}\text { Human } \\
\text { BMSCs }\end{array}$ & NA & $\begin{array}{l}\text { Electromagnetic field at } 5 \mathrm{mT}, 15 \mathrm{~Hz} \\
(45 \mathrm{~min} / 8 \mathrm{~h}, 21 \text { days })\end{array}$ & $\begin{array}{c}\text { Increase gene expression of } \\
\text { COL II and GAG/DNA } \\
\text { content }\end{array}$ & [137] \\
\hline & $\begin{array}{l}\text { Human } \\
\text { BMSCs }\end{array}$ & Stimulate calcium influx & $\begin{array}{l}\text { Electromagnetic field at } 2 \mathrm{mT}, 15 \mathrm{~Hz} \\
\text { for } 10 \text { min once on day } 1 \text { induction }\end{array}$ & $\begin{array}{c}\text { Enhance cartilaginous ECM } \\
\text { deposition and gene } \\
\text { expression of COL II and } \\
\text { SOX9 }\end{array}$ & [138] \\
\hline
\end{tabular}

BMSCs: bone marrow-derived mesenchymal stem cells; MSCs: mesenchymal stem cells; NA: not applicable; LIPUS: low-intensity pulsed ultrasound; ECM: extracellular matrix; PGA: polyglycolic acid; ADSCs: adipose tissue-derived mesenchymal stem cells; COL II: type II collagen; GAG: glycosaminoglycan.

chondrogenic differentiation through controlled release of KGN. For example, Sun et al. developed a collagen/chitosan/hyaluronic acid (HA) scaffold containing poly(lactide-co- glycolide) (PLGA) microspheres for controlled KGN release and cartilage regeneration [35]. Chen et al. fabricated a KGN-conjugated poly(ether-ester-urethane)urea scaffold 


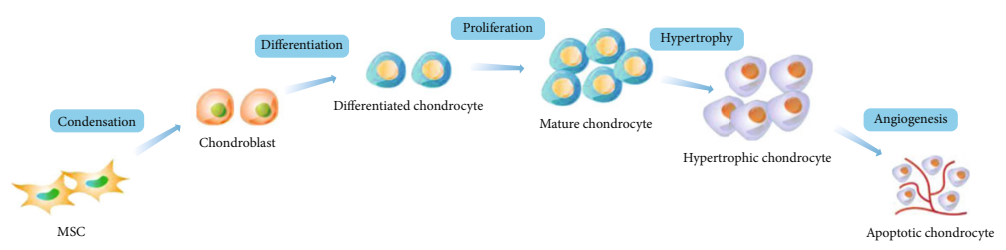

FIGURE 1: Chondrogenic differentiation process of mesenchymal stem cells (MSCs). The chondrogenic differentiation of MSCs is proposed to follow an endochondral ossification procedure, which includes five main stages: condensation, differentiation, proliferation, hypertrophy, and angiogenesis.

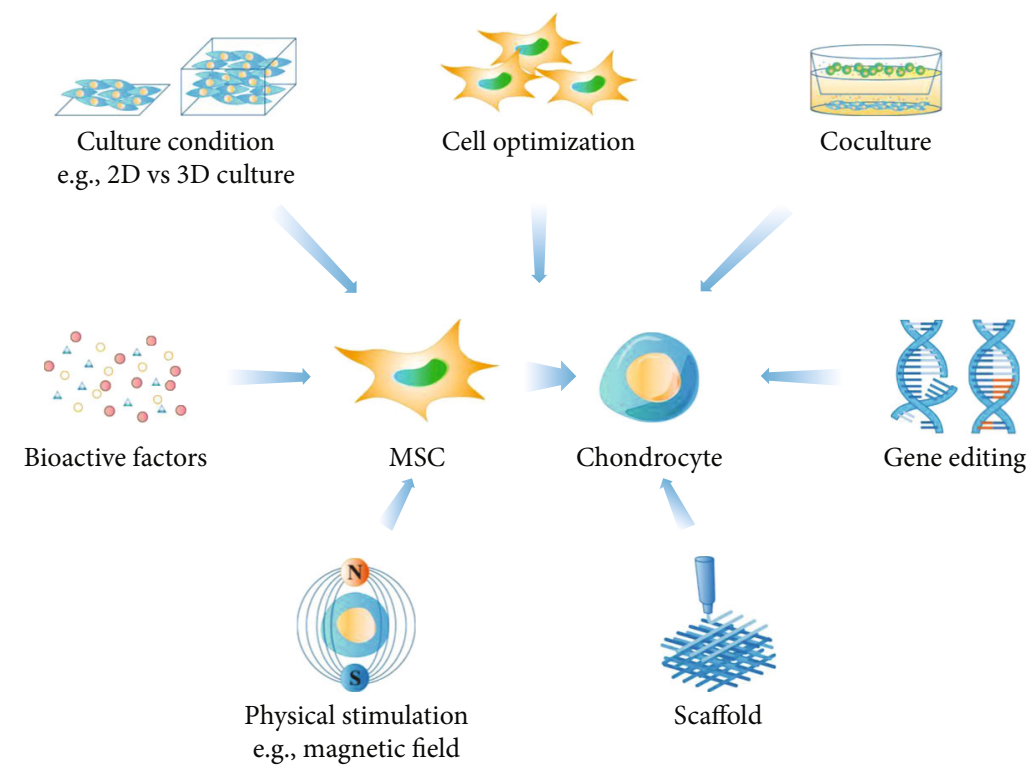

Figure 2: Approaches for enhancing MSC chondrogenic differentiation. Several methods have proven to be effective in promoting chondrogenic differentiation of MSCs, including optimization of bioactive factors, culture conditions, cell type selection, coculture, gene editing, scaffolds, and physical stimulation.

and demonstrated that KGN on the scaffold could undergo stable sustained release, thus enhancing chondrogenic differentiation of hUCMSCs in vitro and cartilage regeneration in rabbits [36].

3.3. Melatonin. Melatonin (N-acetyl-5-methoxytryptamine) is an indolamine that was first isolated from the pineal tissue in 1957 [37]. In addition to participating in the modulation of various physiological functions, such as sleep, circadian rhythms, and neuroendocrine processes, recent studies have suggested that melatonin also plays an important role in regulating MSC differentiation [38, 39]. It has been proven that melatonin enhances hBMSC osteogenic and chondrogenic differentiation while inhibiting adipogenic differentiation $[40,41]$. Gao et al. performed a study in which they induced hBMSC chondrogenic differentiation with chondrogenic medium containing vehicle or melatonin. They found that the synthesis of glycosaminoglycans (GAGs) and COL II and the gene expression levels of ACAN, COL II, and SOX9 were higher in the melatonin group than in the control group. Furthermore, they confirmed that melatonin receptors were expressed on chondrogenic BMSCs. After treatment with a melatonin receptor antagonist, the effect of melatonin on the chondrogenic differentiation of BMSCs was blocked, indicating that melatonin promoted BMSC chondrogenic differentiation at least partially through melatonin receptors [42].

3.4. Chondroitin Sulfate. Chondroitin sulfate (CS), a type of GAG in connective tissues, has shown the capacity to enhance MSC chondrogenic differentiation by providing a chondroinductive microenvironment $[43,44]$. Compared with poly(ethylene glycol) hydrogels, CS-based hydrogels are able to promote both chondrocyte-specific gene expression and cartilage ECM accumulation. Furthermore, CS can inhibit the hypertrophic differentiation of goat BMSCs, as evidenced by significantly downregulated expression of COL $X[45,46]$. The stiffness of the hydrogels also has an impact on the function of CS. CS-containing hydrogels with low mechanical stiffness were reported to lead to more neocartilage deposition than those with high stiffness [47]. CS supplementation has been utilized as a biochemical cue in integrated cartilage tissue engineering. Moura et al. developed 3D porous poly( $\varepsilon$-caprolactone) scaffolds with CS supplementation, which were able to promote hBMSC proliferation, migration, and chondrogenic differentiation [48]. Similarly, Huang et al. fabricated an alginate foam scaffold supplemented with CS and found increased amounts of 
a cartilage-specific matrix in differentiated hBMSC cultures supplemented with CS than in those supplemented with CS-free foams [49].

3.5. Other Factors. In addition to the above bioactive factors, other factors modulating MSC chondrogenic differentiation have also been investigated. Fan et al. demonstrated that ghrelin, also called the "hunger hormone," significantly promoted rat BMSC chondrogenic differentiation, as evidenced by the upregulated expression of COL II, SOX9, and ACAN and enhanced accumulation of collagen and GAGs in vitro, which may be related to increased intracellular phosphorylation of ERK1/2 and DNMT3A. Furthermore, delivery of ghrelin and TGF- $\beta 3$ significantly improved the cartilage repair effect of BMSCs in rats compared with delivery of TGF- $\beta 3$ alone [50]. In addition, $\mathrm{Li}$ et al. reported that atractylenolides, a traditional Chinese medicine, was able to promote rat BMSC chondrogenic differentiation via activation of the Sonic Hedgehog ( $\mathrm{SHH}$ ) signaling pathway [51]. Follistatin-like protein-1 (FSTL-1), an acidic cysteinerich glycoprotein, also plays a role in regulating MSC chondrogenic differentiation [52]. FSTL-1-deficient mouse embryonic skull-derived MSCs exhibited significantly downregulated gene expression of COL2A1 and SOX9, reduced ECM production, and decreased activity of the TGF- $\beta$ signaling pathway [53].

\section{Culture Conditions}

MSCs tend to lose their differentiation potential as a result of culture stress or cell senescence when expanded in vitro. Articular cartilage resides at low oxygen tension (1-4\% oxygen) in vivo [54]. The impact of hypoxia on MSC chondrogenic differentiation has been of particular interest. It was demonstrated that MSCs cultured under low oxygen tension exhibited enhanced early chondrogenic differentiation and reduced hypertrophic differentiation, as evidenced by higher expression levels of the chondrogenic markers COL II, SOX9, and ACAN and lower expression levels of the hypertrophic markers COL $X$ and $M M P 13$ [55-57]. Portron et al. investigated the related intracellular mechanism and confirmed that low oxygen tension increased the DNA-binding activities of two biological effectors, HIF- $1 \alpha$ and HIF- $2 \alpha$, which have been reported to be promoters of human ADSC (hADSC) chondrogenic differentiation [55]. In addition, recent studies of cartilage tissue engineering have investigated the effect of $3 \mathrm{D}$ culture on MSC chondrogenic differentiation, which represents a potential way to mimic the in vivo cartilage tissue environment. Synthetic and natural materials, such as 3D-printed bioreactor chambers, hydrogels, and microspheres, have been developed as tools to create a $3 \mathrm{D}$ microenvironment for MSCs [58-61]. For example, Sulaiman et al. compared the $2 \mathrm{D}$ and $3 \mathrm{D}$ cultures of hBMSCs and found that $3 \mathrm{D}$ culture of BMSCs on gelatin microspheres enhanced their stemness and chondrogenic differentiation compared to $2 \mathrm{D}$ culture on a standard tissue culture plate [61].

\section{Cell Types}

In recent years, many researchers have proposed that MSCs are heterogeneous and that not all share the same chondrogenic differentiation abilities. This heterogeneity was reported to exist among different donors, tissue sources, and cell phenotypes.

Among the various donor characteristics, the effect of donor age on MSC chondrogenic differentiation ability has been most frequently studied. Kanawa et al. isolated BMSCs from 17 patients (25-81 years old) and expanded them with FGF-2 for 28-42 days before differentiation assays. After 28 days of induced culturing, they found that the chondrogenic potential, rather than the osteogenic or adipogenic potential, of BMSCs declines with donor age, as evidenced by decreases in the expression of chondrocyte-specific genes such as SOX9, COL2A, and ACAN. Moreover, the (GAGs)/DNA content also significantly decreased with donor age after chondrogenic differentiation [62]. However, Andrzejewska et al. indicated that the chondrogenic potential of BMSCs was not affected by donor age. They examined the phenotypic and functional performances of BMSCs isolated from adult and elderly patients $(n=10$ and $n=13$, mean age 38 and 72 years old) and found no difference in proteoglycan synthesis between BMSCs (at passage 6) from younger adults and those from older adults after 21 days of chondrogenic differentiation induction [63]. Thus, it is still not clear whether MSC chondrogenic differentiation is affected by donor age, and further studies are needed. On the other hand, Dudics et al. demonstrated that the chondrogenic differentiation ability of BMSCs from OA and RA patients was comparable to that of BMSCs from healthy individuals, as shown by similar COL II gene expression and proteoglycan synthesis after chondrogenic induction, suggesting that BMSCs from $\mathrm{OA}$ and RA patients could also be applied in cartilage tissue engineering [64]. Garci'a-A'lvarez reached a similar conclusion when they found that the chondrogenic differentiation potential of BMSCs from OA patients was similar to that of BMSCs from femoral fracture patients [65].

Conversely, it is well recognized that MSCs from different tissue sources possess different potentials for chondrogenic differentiation. Compared with BMSCs, ADSCs appear to have lower chondrogenic potential [66-68]. MSCs have also been identified in the synovial tissue, a tissue type that is adjacent to articular cartilage. SDSCs have shown higher chondrogenic potential than BMSCs and ADSCs [69]. However, Neybecker revealed that the chondrogenic differentiation potential of SDSCs was lower than that of BMSCs in advanced OA patients, which may be attributed to the intraarticular inflammatory environment caused by $\mathrm{OA}$ [70]. It has also been proposed that the chondrogenic differentiation and ECM production capacities of human amnionand placenta-derived MSCs are higher than those of hADSCs $[71,72]$. The chondrogenic differentiation potential of MSCs derived from the same tissue in different parts of the body also varies. For example, compared with those isolated from the femoral head bone marrow, hBMSCs isolated from the iliac crest and vertebral body bone marrow were more likely to differentiate into chondrocytes and form cartilaginous tissue in vitro [73]. 
MSCs from the same tissue are different in cellular phenotype. $\mathrm{CD} 105^{+} \mathrm{SDSC}$ possess greater chondrogenic potential than $\mathrm{CD} 105^{-}$SDSCs. The promotion of SDSC chondrogenic differentiation by CD105 is achieved through the activation of the TGF- $\beta /$ Smad2 signaling pathway [7476]. Hagmann et al. revealed that after chondrogenic differentiation, $\mathrm{CD}_{146^{+}} \mathrm{hBMSCs}$ produced more GAGs than unsorted BMSCs [77]. Compared with $\mathrm{CD} 106^{+}$or $\mathrm{CD}^{2} 3^{+}$ hSDSCs, CD271 ${ }^{+}$SDSCs exhibited a greater chondrogenic differentiation capacity, as determined by histological and immunohistochemical analyses for COL II [78]. Single-cell RNA sequencing (scRNA-seq) technology can be used to analyze gene expression at the single-cell level, enabling the identification of functional cell subpopulations, making it a powerful tool for investigating MSC heterogeneity [79]. Freeman et al. used scRNA-seq to assess the transcriptional diversity of mouse BMSCs and found that the expression of genes associated with multilineage potential and immunomodulation ability was inconsistent between individual cells [80]. Sun et al. investigated the gene expression profile of human Wharton's jelly MSCs (WJMSCs) via scRNA-seq and found some highly variable genes to be associated with the functional properties of WJMSCs. They found that different subpopulations showed distinct chondrogenic differentiation potency [81]. By performing scRNA-seq of the transcriptome, Liu et al. identified 3 subpopulations within hBMSCs, among which one subpopulation exhibited a strong expression of FGFR2 and potentially included skeletal stem cells [82]. Specifically, Merrick et al. demonstrated that dipeptidyl peptidase-4/CD26 ${ }^{+}$ADSCs represent highly proliferative and multipotent progenitors in murine and human adipose tissues, while their chondrogenic differentiation ability still needs further investigation [83]. Additional research is needed to explore more functional MSC subpopulations via scRNA-seq to identify those with greater chondrogenic differentiation potential.

\section{Coculture}

Coculture was first performed in 1978 by Lawrence et al., who indicated that heterologous cells communicated and responded to cell-specific hormones through cyclic AMP [84]. In recent years, coculture has been applied in cartilage tissue engineering [85]. It was reported that the presence of chondrocytes promoted MSC chondrogenic differentiation in culture [86, 87]. Compared to direct coculture, indirect coculture with human UCBSCs and chondrocytes significantly increased the expression of SOX9 and COL II and decreased the expression of COL $I$ in UCBSCs [88]. Kubosch et al. revealed that coculture of human or swine SDSCs with chondrocytes resulted in greater self-organization, chondrogenic differentiation, and TGF- $\beta$ secretion in SDSCs, suggesting that chondrocytes may induce a chondrogenic phenotype in SDSCs through paracrine action mimicking joint homeostasis $[89,90]$. In vivo ectopic chondrogenic differentiation of swine BMSCs could also be induced by mature chondrocytes, which may be attributed to soluble chondrogenic factors secreted by chondrocytes [91]. In addition, when cocultured with hADSCs, chondrocytes were shown to suppress the undesired hypertrophy of hADSCs [92]. Zhang et al. carried out a study in which human WJMSCs and chondrocytes were cocultured on an acellular cartilage ECM scaffold and transplanted into the articular cartilage defect area in caprine. After 9 months, they found that the neotissue was more similar to native cartilage than that formed by the transplantation of WJMSCs or chondrocytes alone, indicating that coculture represents a promising strategy for improving the cartilage-regenerating effects of MSCs [93]. However, to determine the optimal culture conditions, MSC and chondrocyte cocultures need to be further investigated in more in vivo models. In addition, the impact of coculturing MSCs with other cell types on MSC chondrogenic differentiation should also be evaluated [94].

\section{Gene Editing}

The overexpression and knockdown of specific genes are optional methods to control chondrogenic differentiation in MSCs. DLX5 is a member of the DLX gene family, and DLX5 associates with HOXC8 to form a protein complex. Yang et al. revealed that the expression of both DLX5 and HOXC8 was increased during chondrogenic differentiation of human apical papillae-derived MSCs (APSCs) and that the overexpression of DLX5 and HOXC8 promoted the chondrogenic differentiation of APSCs. In fact, the protein complex formed by DLX5 and HOXC8 could inhibit the activation of LINC01013, a negative regulator of chondrogenesis, by directly binding to its promoter [95]. Similarly, $K L F 15$, a member of the KFL transcription factor family, is also upregulated when hBMSCs undergo chondrogenic differentiation. By binding to the SOX9 promoter, KFL15 was shown to activate SOX9 and enhance the chondrogenic differentiation potential of BMSCs [96]. In addition, Zhou et al. found that corin expression was upregulated in the trilineage differentiation process of hBMSCs. The silencing of corin gene expression inhibited chondrogenic (rather than osteogenic and adipogenic) differentiation of BMSCs, indicating that corin may play a positive role in the regulation of chondrogenic differentiation of BMSCs [97]. Tian et al. demonstrated that miR-30a also plays an important role in chondrogenic differentiation of rat BMSCs by inhibiting DLL4 expression [98]. In another study, Kim et al. fabricated shATF4 and SOX9 plasmid DNA complexed with gene regulation nanoparticles and verified that it could significantly promote the chondrogenic differentiation of hBMSCs [99]. In addition, it was demonstrated that $H-89$ could increase miR-23b expression in human MSCs (hMSCs), thus promoting their chondrogenic differentiation through inhibition of PKA signaling [100]. All of these genes may be potential targets for gene editing to enhance MSC chondrogenic differentiation. However, the safety of gene editing in MSCs needs to be fully explored before this strategy can be applied clinically.

\section{Scaffolds}

Researchers are constantly attempting to fabricate scaffolds that are able to enhance MSC chondrogenic differentiation. It has been proposed that the physical properties of the 
scaffolds are involved in regulating MSC chondrogenic differentiation. Ahmed et al. developed 16 electrospun scaffolds with different stiffness and wettability and revealed that chondrogenic differentiation of ATDC5 cells were enhanced in soft scaffolds with an intermediate wettability as evidenced by an increased level of cartilage-associated gene expression [101]. In another study, Nalluri et al. synthesized a hydrophilic polyurethane scaffold with gel like architecture and found that it enhanced BMSC chondrogenic differentiation, as determined by significantly increased cartilage-specific ECM production [102]. Additionally, the porosity and pore size of scaffolds also play a role in MSC chondrogenic differentiation. Prasopthum et al. demonstrated that 3D-printed scaffolds with micro/nanoporous structures could promote chondrogenic and osteogenic differentiation of hBMSCs better than scaffolds with nonporous structures [103]. It was reported that small-pore scaffolds (pore size of $125-250 \mu \mathrm{m}$ ) were more likely to enhance chondrogenic differentiation and inhibit endochondral ossification of hBMSCs compared with large-pore scaffolds (pore size of $425-600 \mu \mathrm{m}$ ) [104]. Interestingly, Di Luca et al. created scaffolds composed of poly(ethylene oxide therephtalate)/poly(butylene therephtalate) with a structural gradient in pore size. They confirmed that hBMSCs seeded on the gradient scaffolds produced more GAGs as compared with those seeded on nongradient scaffolds [105].

As a biologically complete substrate, ECM has been proposed to provide a native microenvironment for MSCs and to aid in the maintenance of their functions [106, 107]. Coating with ECM has been shown to preserve the stemness and differentiation potential of in vitro-expanded MSCs [108]. Compared with polyglycolic acid (PGA) scaffolds, ECM scaffolds not only enhanced chondrogenic differentiation of rabbit BMSCs more effectively but also maintained the BMSC phenotype for longer in vivo [109]. Li et al. demonstrated that cartilage ECM could not only enhance chondrogenic differentiation but also inhibit hypertrophic differentiation of hBMSCs. Among various ECM collagen subtypes, collagen type XI exhibited the strongest effects on promoting the production and inhibiting the degradation of cartilage matrix [110]. Collagen and GAGs are ideal natural materials that can mimic the matrix niche of chondrocytes and reportedly have an enhancing effect on the chondrogenic differentiation of MSCs [111]. Raghothaman et al. fabricated an interfacial polyelectrolyte complexation-Col I hydrogel and found that it could enhance cell-cell interactions and cellular condensation, thereby resulting in improved hBMSC chondrogenic differentiation and hyaline neocartilage formation [112]. In another study, Meng et al. generated a tricalcium phosphate-collagen-hyaluronan scaffold and found that it efficiently induced chondrogenic differentiation of ATDC5 cells and hBMSCs without the need for exogenous growth factors [113]. Similarly, Moulisová et al. constructed a gelatin-HA hybrid hydrogel and confirmed that it promoted both chondrogenic differentiation and adhesion of hBMSCs [114]. Feng et al. synthesized sulfated HA hydrogels and found that they not only promoted MSC chondrogenic differentiation but also suppressed
hMSC hypertrophy. When utilized to treat OA in rats, the sulfated HA hydrogels significantly reduced cartilage abrasion and hypertrophy [115].

Additionally, previous works have shown that biomaterials can be used as effective delivery vehicles or bioactive matrices to promote MSC chondrogenic differentiation and mitigate MSC hypertrophy. Morille et al. generated PLGAbased microspheres coated with TGF- $\beta 3$ and confirmed their promotion of chondrogenic differentiation of MSCs in vitro. When hBMSCs seeded onto these microspheres were injected into the knee cavities of rats with OA, cartilage-like tissue was formed, and decreased degradation of endogenous articular cartilage was observed after 6 weeks [116]. In addition, $\mathrm{Xu}$ et al. fabricated a multifunctional nanocarrier modified with RGD peptide and $\beta$-cyclodextrin that could carry siRNA targeting Runx2 and small molecules such as KGN. They verified that it was able to induce hMSC differentiation into chondrocytes and suppress their hypertrophy [117]. Remote control of MSC chondrogenic differentiation in vivo via biomaterials has also been achieved. Based on an upconversion nanotransducer, Kang et al. developed a nanocomplex with photolabile caging of KGN and calcium, whose release could be triggered by near-infrared light. They confirmed that intracellular KGN and calcium delivery promoted chondrogenic differentiation and inhibited the hypertrophy of hMSCs in vivo [118].

\section{Physical Stimulation}

9.1. Mechanical Stimulation. Articular cartilage is a smooth wear-resistant connective tissue that can withstand complex mechanical stimuli and distribute loads to the subchondral bone. Proper mechanical stimulation has been revealed to upregulate the gene expression of ACAN and COL II in chondrocytes while maintaining their phenotypes, thus promoting cartilage formation [119-121]. Similarly, an in-depth understanding of the effect of mechanical stimulation on MSC chondrogenic differentiation may facilitate the success of MSC-based cartilage regenerative therapies in joints, which have a mechanically demanding environment. It is proposed that MSCs respond to mechanical stimulation through autocrine or paracrine activity to enhance their chondrogenic differentiation and capacity for repairing cartilage damage. Various types of mechanical stimulation have been applied to enhance MSC chondrogenic differentiation in cartilage tissue engineering [122]. Hou et al. demonstrated that low-magnitude high-frequency vibration enhanced the chondrogenic potential of rat BMSCs through activation of the Wnt/ $\beta$-catenin signaling pathway [123]. Xie et al. revealed that proper tensile mechanical stimulation could improve the viscoelasticity and chondrogenic phenotype of rabbit BMSCs [124]. Additionally, Zhang et al. investigated the effect of deferral dynamic compression on the chondrogenic differentiation of hBMSCs and found that it enhanced chondrogenic differentiation and suppressed chondrocyte hypertrophy, accompanied by the activation of TGF- $\beta /$ Activin/Nodal signaling pathway and suppression of BMP/GDP and integrin/FAK/ERK signaling pathways [125]. Cao et al. performed a similar study in which they applied dynamic 
mechanical loading to rabbit BMSCs-collagen scaffold constructs and found that BMSCs expressed higher levels of ACAN, COL2A1, and SOX9 and lower levels of COL10A1 and COL1A2. The mechanical strength of the constructs was significantly improved and was similar to that of native cartilage [126]. Indian Hedgehog (IHH) and SHH can promote MSC chondrogenic differentiation but tend to result in chondrogenic hypertrophy and ossification. Chen et al. reported that microgravity caused by a rotary cell culture system was able to enhance chondrogenic differentiation of rabbit BMSCs while attenuating the chondrocyte hypertrophy and aging induced by IHH and SHH [28].

In addition, recent studies have demonstrated that lowintensity pulsed ultrasound (LIPUS), which provides mechanical stimulation in the form of sound waves, can be used to promote chondrogenic differentiation of C3H10T1/2 cells [127]. After LIPUS stimulation at $3 \mathrm{MHz}$, BMSCs secreted increased amounts of cartilage-like ECM and showed upregulated expression of chondrogenic genes, such as COL II, SOX9, and ACAN. The stimulatory effect of LIPUS on rat BMSC chondrogenic differentiation is reportedly achieved through inhibition of autography [128]. Cui et al. seeded rabbit BMSCs on a PGA scaffold and implanted the construct into the backs of nude mice, which subsequently received LIPUS stimulation for 10 min every day for 4 weeks. They found that the collagen and GAG content, as well as the mechanical properties, showed a more significant increase in the LIPUS group than in the unstimulated group, suggesting that LIPUS stimulation could promote BMSC chondrogenic differentiation in vivo [129].

9.2. Electric Field. In addition to mechanical stimulation, other physical stimuli, such as electrical and electromagnetic/magnetic stimuli, also have an impact on the chondrogenic differentiation of MSCs [130]. Treatment with a lowfrequency electric field $(\mathrm{EF})$ was reported to result in increased expression of COL II and SOX9 and decreased expression of COL I and COL $X$ in hADSCs [131, 132]. Even in the absence of exogenous growth factors, a low-frequency EF could enhance chondrogenic differentiation of mouse BMSCs. It was demonstrated that EF promoted BMSC chondrogenic differentiation by driving $\mathrm{Ca}^{2+} / \mathrm{ATP}$ oscillations, which are known to play an important role in prechondrogenic condensation. In addition, $\mathrm{EF}$ was found to induce increased TGF- $\beta 1$ expression, and the inhibition of TGF- $\beta$ signaling blocked EF-driven BMSC chondrogenic differentiation, indicating that TGF- $\beta$ signaling mediates EF-driven BMSC chondrogenic differentiation. Other signaling pathways, including BMP signaling and MAPK signaling, have also been proposed to be involved in regulating the effect of $\mathrm{EF}$ treatment on BMSC chondrogenic differentiation [133, 134]. Additionally, Li et al. revealed that nanosecond pulsed EF (nsPEF) downregulated the expression of DMMT1, thus increasing the methylation of the OCT4 and NANOG promotors. As a result, swine BMSCs treated with nsPEF exhibited enhanced trilineage differentiation ability [135].

9.3. Electromagnetic Field. Electromagnetic field (EMF) has also been shown to promote MSC chondrogenic differentia- tion [136]. Mayer-Wagner et al. investigated the impact of EMF on hBMSCs during chondrogenic differentiation and found that BMSCs exposed to a low-frequency EMF ( $5 \mathrm{mT}$ ) showed higher COL II expression, increased (GAGs)/DNA content, and lower COL $X$ expression than those that had not been treated with an EMF [137]. Analogously, Parate et al. demonstrated that optimal hBMSC chondrogenic differentiation was achieved with a brief $(10 \mathrm{~min})$, lowintensity $(2 \mathrm{mT})$ pulsed EMF exposure before chondrogenic induction rather than prolonged and repetitive EMF exposure. Transient receptor potential channels, a conduit for extracellular calcium, might be involved in mediating pulse EMF-driven BMSC chondrogenic differentiation [138].

\section{Conclusions and Perspectives}

MSCs have shown great prospects in cartilage tissue engineering. However, some issues need to be resolved before they can be widely applied. First, MSC-based therapy is largely limited by the ability to obtain and manufacture applicable MSC products because MSCs expanded in vitro are prone to losing their therapeutic potential and safety attributes [139]. Developing strategies to enhance chondrogenic differentiation in MSCs is necessary and has important clinical value for cartilage regeneration. In the present review, we summarized the recent research progress in MSC chondrogenic differentiation modulation, including optimization of bioactive factors, culture conditions, cell type selection, coculture, gene editing, scaffolds, and physical stimulation. Although all of these methods are effective in regulating chondrogenic differentiation of MSCs, the reliability, safety, and degree of difficulty in implementing these methods need to be considered. Second, because MSCs tend to undergo hypertrophy in their chondrogenic differentiation process, it is difficult for them to form hyaline cartilage in vivo [12]. A more comprehensive understanding of embryonic chondrogenesis would be beneficial for guiding MSCs to differentiate into cells with a cartilage phenotype. It has been suggested that MSC chondrogenic differentiation may occur in two different directions: one leading to bone formation via endochondral ossification and the other leading to articular cartilage formation. Although endochondral ossification has been widely used as a model to establish MSC chondrogenic differentiation protocols, chondrogenic differentiation of cartilage chondrocytes should be used instead to alleviate inevitable hypertrophic differentiation [140]. Third, the underlying mechanisms by which endogenous and transplanted MSC function remain to be elucidated. In-depth research has revealed that MSCs can perform a paracrine action and are capable of secreting diverse bioactive molecules, such as growth factors, cytokines, and chemokines $[141,142]$. It is suggested that the chondrogenic differentiation of endogenous MSCs is involved in cartilage regeneration, but this is not necessarily true for implanted MSCs, which mainly work through immunomodulatory functions. To further improve the cartilage-regenerating ability of MSCs, additional strategies to recruit host MSCs and enhance their chondrogenic differentiation are still needed. 
It is also essential to exploit approaches to enhance MSC paracrine and immunomodulatory functions.

\section{Data Availability}

The references used to support the findings of this study are included within the article.

\section{Conflicts of Interest}

The authors declare that there are no conflicts of interest.

\section{Authors' Contributions}

$\mathrm{KZ}$ designed the study, collected data, and contributed to manuscript writing. ZS collected data and contributed to manuscript writing. YY designed the study and figures. MC analyzed data and provided comments. CG, LF, and HL collected data. XS provided the study material. QG and SL designed the study and contributed to manuscript writing. All authors read and approved the final manuscript. KZ and ZS contributed equally to this work.

\section{Acknowledgments}

This work was supported by the National Key R\&D Program of China (2019YFA0110600) and the National Natural Science Foundation of China (81772319).

\section{References}

[1] J. C. Sherwood, J. Bertrand, S. E. Eldridge, and F. Dell'Accio, "Cellular and molecular mechanisms of cartilage damage and repair,” Drug Discovery Today, vol. 19, no. 8, pp. 1172-1177, 2014.

[2] S. W. Choi, G. W. Lee, and K. B. Lee, "Arthroscopic microfracture for osteochondral lesions of the talus: functional outcomes at a mean of 6.7 years in 165 consecutive ankles," The American Journal of Sports Medicine, vol. 48, no. 1, pp. 153$158,2020$.

[3] H. Y. Stevens, B. E. Shockley, N. J. Willett et al., "Particulated juvenile articular cartilage implantation in the knee," Cartilage, vol. 5, no. 2, pp. 74-77, 2013.

[4] H. Yabumoto, Y. Nakagawa, and S. Mukai, "Surgical technique and clinical outcomes of osteochondral autograft transplantation for large osteonecrotic lesions of the femoral condyle with residual normal cartilage: the eyeglass technique," Orthopaedic Journal of Sports Medicine, vol. 7, no. 10, p. 2325967119872446, 2019.

[5] J. N. Liu, A. Agarwalla, D. R. Christian et al., "Return to sport following high tibial osteotomy with concomitant osteochondral allograft transplantation," The American Journal of Sports Medicine, vol. 48, no. 8, pp. 1945-1952, 2020.

[6] J. L. Carey, K. G. Shea, A. Lindahl, H. S. Vasiliadis, C. Lindahl, and L. Peterson, "Autologous chondrocyte implantation as treatment for unsalvageable osteochondritis dissecans: 10to 25-year follow-up," The American Journal of Sports Medicine, vol. 48, no. 5, pp. 1134-1140, 2020.

[7] S. Jiang, W. Guo, G. Tian et al., "Clinical application status of articular cartilage regeneration techniques: tissue-engineered cartilage brings new hope," Stem Cells International, vol. 2020, Article ID 5690252, 16 pages, 2020.

[8] A. Colombini, C. Perucca Orfei, D. Kouroupis et al., "Mesenchymal stem cells in the treatment of articular cartilage degeneration: new biological insights for an old-timer cell," Cytotherapy, vol. 21, no. 12, pp. 1179-1197, 2019.

[9] M. Dominici, K. Le Blanc, I. Mueller et al., "Minimal criteria for defining multipotent mesenchymal stromal cells. The International Society for Cellular Therapy position statement," Cytotherapy, vol. 8, no. 4, pp. 315-317, 2006.

[10] J. Chahal, A. Gómez-Aristizábal, K. Shestopaloff et al., "Bone marrow mesenchymal stromal Cells in patients with osteoarthritis results in overall improvement in pain and symptoms and reduces synovial inflammation," Stem Cells Translational Medicine, vol. 8, no. 8, pp. 746-757, 2019.

[11] H.-K. Chang, P.-H. Kim, D. W. Kim et al., "Coronary stents with inducible VEGF/HGF-secreting UCB-MSCs reduced restenosis and increased re-endothelialization in a swine model," Experimental \& Molecular Medicine, vol. 50, no. 9, pp. 1-14, 2018.

[12] R. A. Somoza, J. F. Welter, D. Correa, and A. I. Caplan, "Chondrogenic differentiation of mesenchymal stem cells: challenges and unfulfilled expectations," Tissue Engineering. Part B, Reviews, vol. 20, no. 6, pp. 596-608, 2014.

[13] K. Pelttari, E. Steck, and W. Richter, "The use of mesenchymal stem cells for chondrogenesis," Injury, vol. 39, no. 1, pp. 58-65, 2008.

[14] M. Griffin, S. Hindocha, and W. S. Khan, "Chondrogenic differentiation of adult MSCs," Current Stem Cell Research \& Therapy, vol. 7, no. 4, pp. 260-265, 2012.

[15] P. Li, Z. Gong, L. D. Shultz, and G. Ren, "Mesenchymal stem cells: from regeneration to cancer," Pharmacology \& Therapeutics, vol. 200, pp. 42-54, 2019.

[16] F. Ng, S. Boucher, S. Koh et al., "PDGF, TGF-beta, and FGF signaling is important for differentiation and growth of mesenchymal stem cells (MSCs): transcriptional profiling can identify markers and signaling pathways important in differentiation of MSCs into adipogenic, chondrogenic, and osteogenic lineages," Blood, vol. 112, no. 2, pp. 295-307, 2008.

[17] J. Massague and D. Wotton, "Transcriptional control by the TGF-beta/Smad signaling system," The EMBO Journal, vol. 19, no. 8, pp. 1745-1754, 2000.

[18] T. I. N. G. XU, M. E. N. G. J. I. E. WU, J. I. A. N. Y. I. N. G. FENG, X. I. N. P. I. N. G. LIN, and Z. H. I. Y. U. A. N. GU, "RhoA/Rho kinase signaling regulates transforming growth factor- $\beta 1$-induced chondrogenesis and actin organization of synovium-derived mesenchymal stem cells through interaction with the Smad pathway," International Journal of Molecular Medicine, vol. 30, no. 5, pp. 1119-1125, 2012.

[19] R. Tuli, S. Tuli, S. Nandi et al., "Transforming growth factor$\beta$-mediated chondrogenesis of human mesenchymal progenitor cells involves $\mathrm{N}$-cadherin and mitogen-activated protein kinase and Wnt signaling cross-talk," The Journal of Biological Chemistry, vol. 278, no. 42, pp. 41227-41236, 2003.

[20] T. Hennig, H. Lorenz, A. Thiel et al., "Reduced chondrogenic potential of adipose tissue derived stromal cells correlates with an altered TGFbeta receptor and BMP profile and is overcome by BMP-6," Journal of Cellular Physiology, vol. 211, no. 3, pp. 682-691, 2007.

[21] H. TAIPALEENMAKI, S. SUOMI, T. HENTUNEN, T. LAITALALEINONEN, and A. SAAMANEN, "Impact of 
stromal cell composition on BMP-induced chondrogenic differentiation of mouse bone marrow derived mesenchymal cells," Experimental Cell Research, vol. 314, no. 13, pp. 2400-2410, 2008.

[22] S. Hagmann, B. Moradi, S. Frank et al., "FGF-2 addition during expansion of human bone marrow-derived stromal cells altersMSCsurface marker distribution and chondrogenic differentiation potential," Cell Proliferation, vol. 46, no. 4, pp. 396-407, 2013.

[23] S. Y. Jeong, J. Ha, M. Lee et al., "Autocrine action of thrombospondin-2 determines the chondrogenic differentiation potential and suppresses hypertrophic maturation of human umbilical cord blood-derived mesenchymal stem cells," Stem Cells, vol. 33, no. 11, pp. 3291-3303, 2015.

[24] Y. Wang, G. Zhu, N. Li, J. Song, L. Wang, and X. Shi, "Small molecules and their controlled release that induce the osteogenic/chondrogenic commitment of stem cells," Biotechnology Advances, vol. 33, no. 8, pp. 1626-1640, 2015.

[25] K. Johnson, S. Zhu, M. S. Tremblay et al., “A stem cell-based approach to cartilage repair," Science, vol. 336, no. 6082, pp. 717-721, 2012.

[26] C. B. Westin, R. B. Trinca, C. Zuliani, I. B. Coimbra, and Â. M. Moraes, "Differentiation of dental pulp stem cells into chondrocytes upon culture on porous chitosan-xanthan scaffolds in the presence of kartogenin," Materials Science \& Engineering. C, Materials for Biological Applications, vol. 80, pp. 594-602, 2017.

[27] T. Spakova, J. Plsikova, D. Harvanova, M. Lacko, S. Stolfa, and J. Rosocha, "Influence of kartogenin on chondrogenic differentiation of human bone marrow-derived MSCs in 2D culture and in co-cultivation with $\mathrm{OA}$ osteochondral explant," Molecules, vol. 23, no. 1, p. 181, 2018.

[28] L. Chen, G. Liu, W. Li, and X. Wu, "Chondrogenic differentiation of bone marrow-derived mesenchymal stem cells following transfection with Indian hedgehog and sonic hedgehog using a rotary cell culture system," Cellular \& Molecular Biology Letters, vol. 24, no. 1, 2019.

[29] E. Music, T. J. Klein, W. B. Lott, and M. R. Doran, “Transforming growth factor-beta stimulates human bone marrow-derived mesenchymal stem/stromal cell chondrogenesis more so than kartogenin," Scientific Reports, vol. 10, no. 1, 2020.

[30] A. Valiani, M. A. Izadi, H. Bahramian, E. Esfandiari, and B. Hashemibeni, "Comparison between the effect of kartogenin and TGF $\beta 3$ on chondrogenesis of human adiposederived stem cells in fibrin scaffold," Bratislavské Lekárske Listy, vol. 118, no. 10, pp. 591-597, 2017.

[31] Y. Zhao, B. Teng, X. Sun et al., "Synergistic effects of kartogenin and transforming growth Factor- $\beta 3$ on chondrogenesis of human umbilical cord mesenchymal stem CellsIn vitro," Orthopaedic Surgery, vol. 12, no. 3, pp. 938-945, 2020.

[32] Q. Zhou, J.-H. Zhang, S. Yuan et al., "A new insight of kartogenin induced the mesenchymal stem cells (MSCs) selectively differentiate into chondrocytes by activating the bone morphogenetic protein 7 (BMP-7)/Smad5 pathway," Medical Science Monitor, vol. 25, pp. 4960-4967, 2019.

[33] H. Jing, X. Zhang, M. Gao et al., "Kartogenin preconditioning commits mesenchymal stem cells to a precartilaginous stage with enhanced chondrogenic potential by modulating JNK and $\beta$-catenin-related pathways," The FASEB Journal, vol. 33, no. 4, pp. 5641-5653, 2019.
[34] J. Granados-Montiel, M. Cruz-Lemini, C. Rangel-Escareño et al., "SERPINA9 and SERPINB2: novel cartilage lineage differentiation markers of human mesenchymal stem cells with kartogenin," Cartilage, vol. 12, 2021.

[35] X. Sun, J. Wang, Y. Wang, and Q. Zhang, "Collagen-based porous scaffolds containing PLGA microspheres for controlled kartogenin release in cartilage tissue engineering," Artif Cells Nanomed Biotechnol, vol. 46, no. 8, pp. 19571966, 2018.

[36] C. Chen, K. Huang, J. Zhu et al., "A novel elastic and controlled-release poly(ether-ester-urethane)urea scaffold for cartilage regeneration," Journal of Materials Chemistry $B$, vol. 8, no. 18, pp. 4106-4121, 2020.

[37] A. A. R. O. N. B. LERNER, J. A. M. E. S. D. CASE, W. A. T. A. R. U. MORI, and M. A. R. G. A. R. E. T. R. WRIGHT, "Melatonin in peripheral nerve," Nature, vol. 183, no. 4678, p. 1821, 1959.

[38] B. Wang, H. Wen, W. Smith, D. Hao, B. He, and L. Kong, "Regulation effects of melatonin on bone marrow mesenchymal stem cell differentiation," Journal of Cellular Physiology, vol. 234, no. 2, pp. 1008-1015, 2019.

[39] F. Luchetti, B. Canonico, D. Bartolini et al., "Melatonin regulates mesenchymal stem cell differentiation: a review," Journal of Pineal Research, vol. 56, no. 4, pp. 382-397, 2014.

[40] C. Hu and L. Li, "Melatonin plays critical role in mesenchymal stem cell-based regenerative medicine in vitro and in vivo," Stem Cell Research \& Therapy, vol. 10, no. 1, p. 13, 2019.

[41] B. Gao, W. Gao, Z. Wu et al., "Melatonin rescued interleukin $1 \beta$-impaired chondrogenesis of human mesenchymal stem cells," Stem Cell Research \& Therapy, vol. 9, no. 1, p. 162, 2018.

[42] W. Gao, M. Lin, A. Liang et al., "Melatonin enhances chondrogenic differentiation of human mesenchymal stem cells," Journal of Pineal Research, vol. 56, no. 1, pp. 62-70, 2014.

[43] W.-C. Chen, C.-L. Yao, I.-M. Chu, and Y.-H. Wei, "Compare the effects of chondrogenesis by culture of human mesenchymal stem cells with various type of the chondroitin sulfate C," Journal of Bioscience and Bioengineering, vol. 111, no. 2, pp. 226-231, 2011.

[44] B. Corradetti, F. Taraballi, S. Minardi et al., "Chondroitin sulfate immobilized on a biomimetic scaffold modulates inflammation while driving chondrogenesis," Stem Cells Translational Medicine, vol. 5, no. 5, pp. 670-682, 2016.

[45] S. Varghese, N. S. Hwang, A. C. Canver, P. Theprungsirikul, D. W. Lin, and J. Elisseeff, "Chondroitin sulfate based niches for chondrogenic differentiation of mesenchymal stem cells," Matrix Biology, vol. 27, no. 1, pp. 12-21, 2008.

[46] E. A. Aisenbrey and S. J. Bryant, "The role of chondroitin sulfate in regulating hypertrophy during MSC chondrogenesis in a cartilage mimetic hydrogel under dynamic loading," Biomaterials, vol. 190-191, pp. 51-62, 2019.

[47] T. Wang and F. Yang, "A comparative study of chondroitin sulfate and heparan sulfate for directing three-dimensional chondrogenesis of mesenchymal stem cells," Stem Cell Research \& Therapy, vol. 8, no. 1, p. 284, 2017.

[48] C. S. Moura, J. C. Silva, S. Faria et al., "Chondrogenic differentiation of mesenchymal stem/stromal cells on $3 \mathrm{D}$ porous poly ( $\varepsilon$-caprolactone) scaffolds: effects of material alkaline treatment and chondroitin sulfate supplementation," Journal of Bioscience and Bioengineering, vol. 129, no. 6, pp. 756-764, 2020. 
[49] Z. Huang, P. Nooeaid, B. Kohl et al., "Chondrogenesis of human bone marrow mesenchymal stromal cells in highly porous alginate-foams supplemented with chondroitin sulfate," Materials Science \& Engineering. C, Materials for Biological Applications, vol. 50, pp. 160-172, 2015.

[50] L. Fan, J. Chen, Y. Tao et al., "Enhancement of the chondrogenic differentiation of mesenchymal stem cells and cartilage repair by ghrelin," Journal of Orthopaedic Research, vol. 37, no. 6, pp. 1387-1397, 2019.

[51] X. Li, G. Wei, X. Wang et al., "Targeting of the Sonic Hedgehog pathway by atractylenolides promotes chondrogenic differentiation of mesenchymal stem cells," Biological \& Pharmaceutical Bulletin, vol. 35, no. 8, pp. 1328-1335, 2012.

[52] W. Li, M. Alahdal, Z. Deng et al., "Molecular functions of FSTL1 in the osteoarthritis," International Immunopharmacology, vol. 83, p. 106465, 2020.

[53] Y. Chaly, H. C. Blair, S. M. Smith et al., "Follistatin-like protein 1 regulates chondrocyte proliferation and chondrogenic differentiation of mesenchymal stem cells," Annals of the Rheumatic Diseases, vol. 74, no. 7, pp. 1467-1473, 2015.

[54] G. Pattappa, B. Johnstone, J. Zellner, D. Docheva, and P. Angele, "The importance of physioxia in mesenchymal stem cell chondrogenesis and the mechanisms controlling its response," International Journal of Molecular Sciences, vol. 20, no. 3, p. 484, 2019.

[55] S. Portron, V. Hivernaud, C. Merceron et al., "Inverse regulation of early and late chondrogenic differentiation by oxygen tension provides cues for stem cell-based cartilage tissue engineering," Cellular Physiology and Biochemistry, vol. 35, no. 3, pp. 841-857, 2015.

[56] V. V. Meretoja, R. L. Dahlin, S. Wright, F. K. Kasper, and A. G. Mikos, "The effect of hypoxia on the chondrogenic differentiation of co-cultured articular chondrocytes and mesenchymal stem cells in scaffolds," Biomaterials, vol. 34, no. 17, pp. 4266-4273, 2013.

[57] E. J. Sheehy, C. T. Buckley, and D. J. Kelly, "Oxygen tension regulates the osteogenic, chondrogenic and endochondral phenotype of bone marrow derived mesenchymal stem cells," Biochemical and Biophysical Research Communications, vol. 417, no. 1, pp. 305-310, 2012.

[58] A. J. Janvier, E. Canty-Laird, and J. R. Henstock, “A universal multi-platform 3D printed bioreactor chamber for tendon tissue engineering," Journal of Tissue Engineering, vol. 11, Article ID 204173142094246, 2020.

[59] K. T. L. Trinh, N. X. T. Le, and N. Y. Lee, "Chitosan-polydopamine hydrogel complex: a novel green adhesion agent for reversibly bonding thermoplastic microdevice and its application for cell-friendly microfluidic 3D cell culture," Lab on a Chip, vol. 20, no. 19, pp. 3524-3534, 2020.

[60] S. J. Bidarra and C. C. Barrias, "3D culture of mesenchymal stem cells in alginate hydrogels," Methods in Molecular Biology, vol. 2002, pp. 165-180, 2019.

[61] S. Sulaiman, S. R. Chowdhury, M. B. Fauzi et al., "3D culture of MSCs on a gelatin microsphere in a dynamic culture system enhances chondrogenesis," International Journal of Molecular Sciences, vol. 21, no. 8, p. 2688, 2020.

[62] M. Kanawa, A. Igarashi, V. S. Ronald et al., “Age-dependent decrease in the chondrogenic potential of human bone marrow mesenchymal stromal cells expanded with fibroblast growth factor-2," Cytotherapy, vol. 15, no. 9, pp. 1062-1072, 2013.
[63] A. Andrzejewska, R. Catar, J. Schoon et al., "Multi-parameter analysis of biobanked human bone marrow stromal cells shows little influence for donor age and mild comorbidities on phenotypic and functional properties," Frontiers in Immunology, vol. 10, 2019.

[64] V. Dudics, A. Kunstár, J. Kovács et al., "Chondrogenic potential of mesenchymal stem cells from patients with rheumatoid arthritis and osteoarthritis: measurements in a microculture system," Cells, Tissues, Organs, vol. 189, no. 5, pp. 307-316, 2009.

[65] F. García-Álvarez, E. Alegre-Aguarón, P. Desportes et al., "Chondrogenic differentiation in femoral bone marrowderived mesenchymal cells (MSC) from elderly patients suffering osteoarthritis or femoral fracture," Archives of Gerontology and Geriatrics, vol. 52, no. 2, pp. 239-242, 2011.

[66] M. A. R. T. I. N. A. VIDAL, S. A. N. D. R. A. O. ROBINSON, M. A. N. D. I. J. LOPEZ et al., "Comparison of chondrogenic potential in equine mesenchymal stromal cells derived from adipose tissue and bone marrow," Veterinary Surgery, vol. 37, no. 8, pp. 713-724, 2008.

[67] X. Xie, Y. Wang, C. Zhao et al., "Comparative evaluation of MSCs from bone marrow and adipose tissue seeded in PRP-derived scaffold for cartilage regeneration," Biomaterials, vol. 33, no. 29, pp. 7008-7018, 2012.

[68] C. C. Ude, S. B. Sulaiman, N. Min-Hwei et al., "Cartilage regeneration by chondrogenic induced adult stem cells in osteoarthritic sheep model," PLoS One, vol. 9, no. 6, article e98770, 2014.

[69] J. Fan, R. R. Varshney, L. Ren, D. Cai, and D. A. Wang, "Synovium-derived mesenchymal stem cells: a new cell source for musculoskeletal regeneration," Tissue Engineering. Part B, Reviews, vol. 15, no. 1, pp. 75-86, 2009.

[70] P. Neybecker, C. Henrionnet, E. Pape et al., "Respective stemness and chondrogenic potential of mesenchymal stem cells isolated from human bone marrow, synovial membrane, and synovial fluid," Stem Cell Research \& Therapy, vol. 11, no. 1, p. 316, 2020.

[71] N. Topoluk, R. Hawkins, J. Tokish, and J. Mercuri, “Amniotic mesenchymal stromal cells exhibit preferential osteogenic and chondrogenic differentiation and enhanced matrix production compared with adipose mesenchymal stromal cells," The American Journal of Sports Medicine, vol. 45, no. 11, pp. 2637-2646, 2017.

[72] G. S. Huang, L. G. Dai, B. L. Yen, and S. H. Hsu, "Spheroid formation of mesenchymal stem cells on chitosan and chitosan- hyaluronan membranes," Biomaterials, vol. 32, no. 29, pp. 6929-6945, 2011.

[73] M. Herrmann, M. Hildebrand, U. Menzel et al., "Phenotypic characterization of bone marrow mononuclear cells and derived stromal cell populations from human iliac crest, vertebral body and femoral head," International Journal of Molecular Sciences, vol. 20, no. 14, p. 3454, 2019.

[74] W. Fan, J. Li, Y. Wang et al., "CD105 promotes chondrogenesis of synovium-derived mesenchymal stem cells through Smad2 signaling," Biochemical and Biophysical Research Communications, vol. 474, no. 2, pp. 338-344, 2016.

[75] C. B. Chang, S. A. Han, E. M. Kim, S. Lee, S. C. Seong, and M. C. Lee, "Chondrogenic potentials of human synoviumderived cells sorted by specific surface markers," Osteoarthritis and Cartilage, vol. 21, no. 1, pp. 190-199, 2013.

[76] J. Qi, A. Chen, H. You, K. Li, and F. G. Di Zhang, "Proliferation and chondrogenic differentiation of CD105-positive 
enriched rat synovium-derived mesenchymal stem cells in three-dimensional porous scaffolds," Biomedical Materials, vol. 6, no. 1, p. 015006, 2011.

[77] S. Hagmann, S. Frank, T. Gotterbarm, T. Dreher, V. Eckstein, and B. Moradi, "Fluorescence activated enrichment of CD146 + cells during expansion of human bone-marrow derived mesenchymal stromal cells augments proliferation and GAG/DNA content in chondrogenic media," BMC Musculoskeletal Disorders, vol. 15, no. 1, 2014.

[78] M. C. Arufe, A. De la Fuente, I. Fuentes, F. J. de Toro, and F. J. Blanco, "Chondrogenic potential of subpopulations of cells expressing mesenchymal stem cell markers derived from human synovial membranes," Journal of Cellular Biochemistry, vol. 111, no. 4, pp. 834-845, 2010.

[79] G. Zheng, Z.-Y. Xie, P. Wang, Y.-F. Wu, and H.-Y. Shen, "Recent advances of single-cell RNA sequencing technology in mesenchymal stem cell research," World Journal of Stem Cells, vol. 12, no. 6, pp. 438-447, 2020.

[80] B. T. Freeman, J. P. Jung, and B. M. Ogle, "Single-cell RNASeq of bone marrow-derived mesenchymal stem cells reveals unique profiles of lineage priming," PLoS One, vol. 10, no. 9, article e0136199, 2015.

[81] C. Sun, L. Wang, H. Wang et al., "Single-cell RNA-seq highlights heterogeneity in human primary Wharton's jelly mesenchymal stem/stromal cells cultured in vitro," Stem Cell Research \& Therapy, vol. 11, no. 1, p. 149, 2020.

[82] S. Liu, D. F. Stroncek, Y. Zhao et al., "Single cell sequencing reveals gene expression signatures associated with bone marrow stromal cell subpopulations and time in culture," Journal of Translational Medicine, vol. 17, no. 1, p. 23, 2019.

[83] D. Merrick, A. Sakers, Z. Irgebay et al., "Identification of a mesenchymal progenitor cell hierarchy in adipose tissue," Science, vol. 364, no. 6438, p. eaav2501, 2019.

[84] T. S. Lawrence, W. H. Beers, and N. B. Gilula, "Transmission of hormonal stimulation by cell-to-cell communication," Nature, vol. 272, no. 5653, pp. 501-506, 1978.

[85] Y. Zhang, W. Guo, M. Wang et al., "Co-culture systemsbased strategies for articular cartilage tissue engineering," Journal of Cellular Physiology, vol. 233, no. 3, pp. 19401951, 2018.

[86] M. M. Pleumeekers, L. Nimeskern, J. L. M. Koevoet, M. Karperien, K. S. Stok, and G. J. V. M. van Osch, "Trophic effects of adipose-tissue-derived and bone-marrow-derived mesenchymal stem cells enhance cartilage generation by chondrocytes in co-culture," PLoS One, vol. 13, no. 2, article e0190744, 2018.

[87] C. Acharya, A. Adesida, P. Zajac et al., "Enhanced chondrocyte proliferation and mesenchymal stromal cells chondrogenesis in coculture pellets mediate improved cartilage formation," Journal of Cellular Physiology, vol. 227, no. 1, pp. 88-97, 2012.

[88] X. Li, L. Duan, Y. Liang, W. Zhu, J. Xiong, and D. Wang, "Human umbilical cord blood-derived mesenchymal stem cells contribute to chondrogenesis in coculture with chondrocytes," BioMed Research International, vol. 2016, Article ID 3827057, 2016.

[89] E. J. Kubosch, E. Heidt, A. Bernstein, K. Böttiger, and H. Schmal, "The trans-well coculture of human synovial mesenchymal stem cells with chondrocytes leads to self-organization, chondrogenic differentiation, and secretion of TGF $\beta$," Stem Cell Research \& Therapy, vol. 7, no. 1, p. 64, 2016.
[90] F. Zhang, K. Su, Y. Fang, S. Sandhya, and D. A. Wang, "A mixed co-culture of mesenchymal stem cells and transgenic chondrocytes in alginate hydrogel for cartilage tissue engineering," Journal of Tissue Engineering and Regenerative Medicine, vol. 9, no. 1, pp. 77-84, 2015.

[91] X. Liu, H. Sun, D. Yan et al., “_In vivo_ectopic chondrogenesis of BMSCs directed by mature chondrocytes," Biomaterials, vol. 31, no. 36, pp. 9406-9414, 2010.

[92] R. Ramezanifard, M. Kabiri, and H. Hanaee Ahvaz, "Effects of platelet rich plasma and chondrocyte co-culture on MSC chondrogenesis, hypertrophy and pathological responses," EXCLI Journal, vol. 16, pp. 1031-1045, 2017.

[93] Y. Zhang, C. Hao, W. Guo et al., "Co-culture of hWJMSCs and pACs in double biomimetic ACECM oriented scaffold enhances mechanical properties and accelerates articular cartilage regeneration in a caprine model," Stem Cell Research \& Therapy, vol. 11, no. 1, 2020.

[94] K. M. Hubka, R. L. Dahlin, V. V. Meretoja, F. K. Kasper, and A. G. Mikos, "Enhancing chondrogenic phenotype for cartilage tissue engineering: monoculture and coculture of articular chondrocytes and mesenchymal stem cells," Tissue Engineering. Part B, Reviews, vol. 20, no. 6, pp. 641-654, 2014.

[95] H. Yang, Y. Cao, J. Zhang et al., "DLX5 and HOXC8 enhance the chondrogenic differentiation potential of stem cells from apical papilla via LINC01013," Stem Cell Research \& Therapy, vol. 11, no. 1, 2020.

[96] Z. Song, X. Lian, Y. Wang, Y. Xiang, and G. Li, "KLF15 regulates_in vitro_chondrogenic differentiation of human mesenchymal stem cells by targeting SOX9," Biochemical and Biophysical Research Communications, vol. 493, no. 2, pp. 1082-1088, 2017.

[97] H. Zhou, J. Zhu, M. Liu, Q. Wu, and N. Dong, "Role of the protease corin in chondrogenic differentiation of human bone marrow-derived mesenchymal stem cells," Journal of Tissue Engineering and Regenerative Medicine, vol. 12, no. 4, pp. 973-982, 2018.

[98] Y. Tian, R. Guo, B. Shi, L. Chen, L. Yang, and Q. Fu, "MicroRNA-30a promotes chondrogenic differentiation of mesenchymal stem cells through inhibiting Delta-like 4 expression," Life Sciences, vol. 148, pp. 220-228, 2016.

[99] H. J. Kim, S. W. Yi, H. J. Oh, J. S. Lee, J. S. Park, and K. H. Park, "Transfection of gene regulation nanoparticles complexed with pDNA and shRNA controls multilineage differentiation of hMSCs," Biomaterials, vol. 177, pp. 1-13, 2018.

[100] O. Ham, B. W. Song, S. Y. Lee et al., "The role of microRNA$23 \mathrm{~b}$ in the differentiation of MSC into chondrocyte by targeting protein kinase A signaling," Biomaterials, vol. 33, no. 18, pp. 4500-4507, 2012.

[101] M. Ahmed, T. A. da Silva Ramos, F. Damanik et al., “A combinatorial approach towards the design of nanofibrous scaffolds for chondrogenesis," Scientific Reports, vol. 5, no. 1, 2015.

[102] S. M. Nalluri, G. R. Krishnan, C. Cheah et al., "Hydrophilic polyurethane matrix promotes chondrogenesis of mesenchymal stem cells," Materials Science \& Engineering. C, Materials for Biological Applications, vol. 54, pp. 182-195, 2015.

[103] A. Prasopthum, M. Cooper, K. M. Shakesheff, and J. Yang, "Three-dimensional printed scaffolds with controlled micro-/nanoporous surface topography direct chondrogenic and osteogenic differentiation of mesenchymal stem cells," 
ACS Applied Materials \& Interfaces, vol. 11, no. 21, pp. 18896-18906, 2019.

[104] M. J. Gupte, W. B. Swanson, J. Hu et al., "Pore size directs bone marrow stromal cell fate and tissue regeneration in nanofibrous macroporous scaffolds by mediating vascularization," Acta Biomaterialia, vol. 82, pp. 1-11, 2018.

[105] A. Di Luca, K. Szlazak, I. Lorenzo-Moldero et al., "Influencing chondrogenic differentiation of human mesenchymal stromal cells in scaffolds displaying a structural gradient in pore size," Acta Biomaterialia, vol. 36, pp. 210-219, 2016.

[106] C. P. Ng, A. R. Mohamed Sharif, D. E. Heath et al., "Enhanced _ex vivo_expansion of adult mesenchymal stem cells by fetal mesenchymal stem cell ECM," Biomaterials, vol. 35, no. 13, pp. 4046-4057, 2014.

[107] X.-D. Chen, V. Dusevich, J. Q. Feng, S. C. Manolagas, and R. L. Jilka, "Extracellular matrix made by bone marrow cells facilitates expansion of marrow-derived mesenchymal progenitor cells and prevents their differentiation into osteoblasts," Journal of Bone and Mineral Research, vol. 22, no. 12, pp. 1943-1956, 2007.

[108] Y. Xiong, J. He, W. Zhang, G. Zhou, Y. Cao, and W. Liu, "Retention of the stemness of mouse adipose-derived stem cells by their expansion on human bone marrow stromal cell-derived extracellular matrix," Tissue Engineering. Part A, vol. 21, no. 11-12, pp. 1886-1894, 2015.

[109] K. H. Choi, B. H. Choi, S. R. Park, B. J. Kim, and B. H. Min, "The chondrogenic differentiation of mesenchymal stem cells on an extracellular matrix scaffold derived from porcine chondrocytes," Biomaterials, vol. 31 , no. 20, pp. 5355-5365, 2010.

[110] A. Li, Y. Wei, C. Hung, and G. Vunjak-Novakovic, "Chondrogenic properties of collagen type XI, a component of cartilage extracellular matrix," Biomaterials, vol. 173, pp. 47-57, 2018.

[111] Y. Y. Li, T. H. Choy, F. C. Ho, and P. B. Chan, "Scaffold composition affects cytoskeleton organization, cell-matrix interaction and the cellular fate of human mesenchymal stem cells upon chondrogenic differentiation," Biomaterials, vol. 52, pp. 208-220, 2015.

[112] D. Raghothaman, M. F. Leong, T. C. Lim et al., "Engineering cell matrix interactions in assembled polyelectrolyte fiber hydrogels for mesenchymal stem cell chondrogenesis," Biomaterials, vol. 35, no. 9, pp. 2607-2616, 2014.

[113] F. Meng, A. He, Z. Zhang et al., "Chondrogenic differentiation of ATDC5 and hMSCs could be induced by a novel scaffoldtricalcium phosphate-collagen-hyaluronan without any exogenous growth factors in vitro," Journal of Biomedical Materials Research. Part A, vol. 102, no. 8, pp. 2725-2735, 2014.

[114] V. Moulisová, S. Poveda-Reyes, E. Sanmartín-Masiá, L. Quintanilla-Sierra, M. Salmerón-Sánchez, and G. G. Ferrer, "Hybrid protein-glycosaminoglycan hydrogels promote chondrogenic stem cell differentiation," ACS Omega, vol. 2, no. 11, pp. 7609-7620, 2017.

[115] Q. Feng, S. Lin, K. Zhang et al., "Sulfated hyaluronic acid hydrogels with retarded degradation and enhanced growth factor retention promote hMSC chondrogenesis and articular cartilage integrity with reduced hypertrophy," Acta Biomaterialia, vol. 53, pp. 329-342, 2017.

[116] M. Morille, K. Toupet, C. N. Montero-Menei, C. Jorgensen, and D. Noël, "PLGA-based microcarriers induce mesenchymal stem cell chondrogenesis and stimulate cartilage repair in osteoarthritis," Biomaterials, vol. 88, pp. 60-69, 2016.
[117] J. Xu, J. Li, S. Lin et al., "Nanocarrier-mediated codelivery of small molecular drugs and siRNA to enhance chondrogenic differentiation and suppress hypertrophy of human mesenchymal stem cells," Science Advances, vol. 26, no. 15, pp. 2463-2472, 2016.

[118] H. Kang, K. Zhang, Q. Pan et al., "Remote control of intracellular calcium using upconversion nanotransducers regulates stem cell differentiation in vivo," Advanced Functional Materials, vol. 28, no. 41, 2018.

[119] C. Chen, D. T. Tambe, L. Deng, and L. Yang, "Biomechanical properties and mechanobiology of the articular chondrocyte," American Journal of Physiology. Cell Physiology, vol. 305, no. 12, pp. C1202-C1208, 2013.

[120] J. Liu, I. Sekiya, K. Asai, T. Tada, T. Kato, and N. Matsui, "Biosynthetic response of cultured articular chondrocytes to mechanical vibration," Res Exp Med (Berl), vol. 200, no. 3, pp. 183-193, 2001.

[121] E. Kozhemyakina, A. B. Lassar, and E. Zelzer, "A pathway to bone: signaling molecules and transcription factors involved in chondrocyte development and maturation," Development, vol. 142, no. 5, pp. 817-831, 2015.

[122] N. Fahy, M. Alini, and M. J. Stoddart, "Mechanical stimulation of mesenchymal stem cells: implications for cartilage tissue engineering," Journal of Orthopaedic Research, vol. 36, no. 1, pp. 52-63, 2018.

[123] W. Hou, D. Zhang, X. Feng, and Y. Zhou, "Low magnitude high frequency vibration promotes chondrogenic differentiation of bone marrow stem cells with involvement of $\beta$ catenin signaling pathway," Archives of Oral Biology, vol. 118, p. 104860, 2020.

[124] Y. Xie, X. Liu, S. Wang, M. Wang, and G. Wang, "Proper mechanical stimulation improve the chondrogenic differentiation of mesenchymal stem cells: improve the viscoelasticity and chondrogenic phenotype," Biomedicine \& Pharmacotherapy, vol. 115, p. 108935, 2019.

[125] T. Zhang, F. Wen, Y. Wu et al., "Cross-talk between TGFbeta/SMAD and integrin signaling pathways in regulating hypertrophy of mesenchymal stem cell chondrogenesis under deferral dynamic compression," Biomaterials, vol. 38, pp. 72$85,2015$.

[126] W. Cao, W. Lin, H. Cai et al., "Dynamic mechanical loading facilitated chondrogenic differentiation of rabbit BMSCs in collagen scaffolds," Regen Biomater, vol. 6, no. 2, pp. 99106, 2019.

[127] S. M. Z. Uddin, B. Richbourgh, Y. Ding et al., "Chondro-protective effects of low intensity pulsed ultrasound," Osteoarthritis and Cartilage, vol. 24, no. 11, pp. 1989-1998, 2016.

[128] X. Wang, Q. Lin, T. Zhang et al., "Low-intensity pulsed ultrasound promotes chondrogenesis of mesenchymal stem cells via regulation of autophagy," Stem Cell Research \& Therapy, vol. 10, no. 1, p. 41, 2019.

[129] J. H. Cui, K. Park, S. R. Park, and B. H. Min, "Effects of lowintensity ultrasound on chondrogenic differentiation of mesenchymal stem cells embedded in polyglycolic acid: an in vivo study," Tissue Engineering, vol. 12, no. 1, pp. 75-82, 2006.

[130] I. Uzieliene, P. Bernotas, A. Mobasheri, and E. Bernotiene, "The role of physical stimuli on calcium channels in chondrogenic differentiation of mesenchymal stem cells," International Journal of Molecular Sciences, vol. 19, no. 10, p. 2998, 2018.

[131] E. Esfandiari, M. Mardani, S. Roshankhah, B. Hashemibeni, M. Salahshoor, and E. Naghsh, "Induction of chondrogenic 
differentiation of human adipose-derived stem cells by low frequency electric field," Advanced Biomedical Research, vol. 5, 2016.

[132] S. D. McCullen, J. P. McQuilling, R. M. Grossfeld, J. L. Lubischer, L. I. Clarke, and E. G. Loboa, "Application of low-frequency alternating current electric fields via interdigitated electrodes: effects on cellular viability, cytoplasmic calcium, and osteogenic differentiation of human adiposederived stem cells," Tissue Engineering. Part C, Methods, vol. 16, no. 6, pp. 1377-1386, 2010.

[133] H. J. Kwon, G. S. Lee, and H. Chun, "Electrical stimulation drives chondrogenesis of mesenchymal stem cells in the absence of exogenous growth factors," Scientific Reports, vol. 6, no. 1, p. 39302, 2016.

[134] T. Ning, Department of Biomedical Engineering, College of Engineering, Peking University, Beijing, 100871, China, K. Zhang, B. C. Heng, and Z. Ge, "Diverse effects of pulsed electrical stimulation on cells - with a focus on chondrocytes and cartilage regeneration," European Cells \& Materials, vol. 38, pp. 79-93, 2019.

[135] K. Li, T. Ning, H. Wang, Y. Jiang, J. Zhang, and Z. Ge, "Nanosecond pulsed electric fields enhance mesenchymal stem cells differentiation via DNMT1-regulated OCT4/NANOG gene expression," Stem Cell Research \& Therapy, vol. 11, no. 1, p. 308, 2020.

[136] C. L. Ross, M. Siriwardane, G. Almeida-Porada et al., "The effect of low-frequency electromagnetic field on human bone marrow stem/progenitor cell differentiation," Stem Cell Research, vol. 15, no. 1, pp. 96-108, 2015.

[137] S. Mayer-Wagner, A. Passberger, B. Sievers et al., "Effects of low frequency electromagnetic fields on the chondrogenic differentiation of human mesenchymal stem cells," Bioelectromagnetics, vol. 32, no. 4, pp. 283-290, 2011.

[138] D. Parate, A. Franco-Obregón, J. Fröhlich et al., "Enhancement of mesenchymal stem cell chondrogenesis with shortterm low intensity pulsed electromagnetic fields," Scientific Reports, vol. 7, no. 1, p. 9421, 2017.

[139] E. T. Camilleri, M. P. Gustafson, A. Dudakovic et al., "Identification and validation of multiple cell surface markers of clinical-grade adipose-derived mesenchymal stromal cells as novel release criteria for good manufacturing practicecompliant production," Stem Cell Research \& Therapy, vol. 7, no. 1, p. 107, 2016.

[140] X. Tang, Department of Biomedical Engineering, College of Engineering, Peking University, P R China, 100871, L. Fan, M. Pei, L. Zeng, and Z. Ge, "Evolving concepts of chondrogenic differentiation: history, state-of-the-art and future perspectives," European Cells \& Materials, vol. 30, pp. 12-27, 2015.

[141] L. da Silva Meirelles, A. M. Fontes, D. T. Covas, and A. I. Caplan, "Mechanisms involved in the therapeutic properties of mesenchymal stem cells," Cytokine \& Growth Factor Reviews, vol. 20, no. 5-6, pp. 419-427, 2009.

[142] R. M. Samsonraj, M. Raghunath, V. Nurcombe, J. H. Hui, A. J. van Wijnen, and S. M. Cool, "Concise review: multifaceted characterization of human mesenchymal stem cells for use in regenerative medicine," Stem Cells Translational Medicine, vol. 6, no. 12, pp. 2173-2185, 2017. 